\title{
In Vitro Seed and Clonal Propagation of the Mediterranean Aromatic and Medicinal Plant Teucrium capitatum
}

\author{
Maria Papafotiou ${ }^{1}$ and Aekaterini N. Martini \\ Laboratory of Floriculture and Landscape Architecture, Department of Crop \\ Science, Agricultural University of Athens, Iera Odos 75, 11855 Athens, \\ Greece
}

Additional index words. micropropagation, seed pretreatments, germination conditions, explant origin, cytokinin, rooting, native xerophytic ornamentals

\begin{abstract}
The effect of various pretreatments, culture conditions, and storage time on in vitro germination of seeds, as well as the effect of explant origin and plant growth regulators on in vitro propagation of Teucrium capitatum L. (Teucrium polium sp. capitatum Arcang., Lamiaceae) were examined. Seeds, collected from native plants and stored at room temperature for 3,7 , and 12 months, were cultured for germination in vitro in petri dishes with solid half-strength ( $1 / 2)$ Murashige and Skoog (1962) growth medium (MS) at $5,10,15,20,25$, and $30^{\circ} \mathrm{C}$, and 16 hours light or continuous darkness. Pretreatments, such as cold stratification, scarification with sandpaper, dipping in concentrated sulfuric acid $\left(\mathrm{H}_{2} \mathrm{SO}_{4}>95 \%\right)$, or dipping in boiling water were tested. Seeds without any pretreatment germinated at lower than $10 \%$. Dipping in concentrated $\mathrm{H}_{2} \mathrm{SO}_{4}$ for 15 or 20 minutes was the most effective pretreatment, but still seed germination achieved was low $(36 \%)$. Seeds preserved their germination capacity for at least 1 year, and germinated satisfactorily at a wide temperature range, from 15 to $25^{\circ} \mathrm{C}$ (optimum), while photoperiod did not affect seed germination. Explants excised from in vitro-grown seedlings were established in vitro on MS medium with $1.0 \mathrm{mg} \cdot \mathrm{L}^{-1}$ 6-benzyladenine $(\mathrm{BA})$ at much higher rates $(\approx \mathbf{9 0} \%)$ compared with those collected from plants grown from cuttings in a greenhouse $(25 \%)$, while explants collected from adult wild plants failed to do so. Explants from seedlings showed strong variability in their response; those excised from branched seedlings formed shoots at significantly higher percentage $(90 \%)$ at the establishment stage (cultured on MS medium with $\left.0.5-2.0 \mathrm{mg} \cdot \mathrm{L}^{-1} \mathrm{BA}\right)$ than explants excised from unbranched seedlings (36\% to $43 \%$ ), while during subcultures on MS medium with $1.0 \mathrm{mg} \cdot \mathrm{L}^{-1} \mathrm{BA}$, explants from branched seedlings also showed higher multiplication rates than those from unbranched ones. BA at $0.5-2.0 \mathrm{mg} \cdot \mathrm{L}^{-1}$ induced shoot multiplication during both establishment and multiplication stages (7-8 and 14-15 shoots per explant, respectively), while kinetin and $6-\gamma-\gamma$-(dimethylallylamino)-purine (2iP) were less effective than BA, and zeatin the least appropriate. Microshoot rooting was enhanced by 1-week culture on (1/2) MS medium with $1.0-4.0 \mathrm{mg} \cdot \mathrm{L}^{-1}$ indole-3-butyric acid (IBA), followed by transfer to auxin-free, (1/2) MS medium ( $93 \%$ to $98 \%, 7-8$ roots per microshoot), compared with culture on the same medium continuously for 5 weeks $(69 \%$ to $80 \%, 5-6$ roots per microshoot) or at lower IBA concentrations. Plantlets were acclimatized to ex vitro conditions at $98 \%$ on a peatperlite $(1: 1, \mathrm{v} / \mathrm{v})$ mixture.
\end{abstract}

Teucrium capitatum (T. polium sp. capitatum Arcang.) is a strongly aromatic evergreen dwarf shrub, grown in dry areas of the Mediterranean region from the sea level up to 2000-m altitude. This xerophytic herb has characteristic gray-green hairy stems and bears white flowers in compound heads from April until June (Blamey and Grey-Wilson,

Received for publication 23 Oct. 2015. Accepted for publication $28 \mathrm{Feb} .2016$.

This research was funded by NSRF 2007-2013, Operational Program "Education and Lifelong Learning"-funded research project: Thales - "Integrated management of vegetation at archaeological sites to protect monuments and enhance the historical landscape"- "ARCHAEOSCAPE," MIS code 380237.

${ }^{1}$ Corresponding author. E-mail: mpapaf@aua.gr. from various parts of it, mainly terpenoids and flavonoids, which possess a broad spectrum of pharmacological properties including antioxidant, anticancer, anti-inflammatory, hypoglycemic, hepatoprotective, hypolipidemic, antibacterial, and antifungal (Bahramikia and Yazdanparast, 2012).

Apart from medicinal uses, T. capitatum could be introduced as an ornamental landscape plant, suitable for xeriscaping, particularly for dry, rocky places, in calcareous and gypsum soils (Romão and Escudero, 2005), or for urban green roofs in arid and semiarid areas. It could also be used in landscape restoration of East Mediterranean archaeological sites, due to its continuous use since ancient times in the area, as a medicinal and insect repelling plant (Theophrastus, Historia Plantarum, vol. 9, c. 350 BC-c. 287 BC).

Wild populations of $T$. capitatum are subjected to pressure because of selective collection for use in traditional medicine and overgrazing, especially from domestic goats, which very frequently select it in their diet (Barroso et al., 1995), as well as of deforestation and habitat encroachment by urban and agricultural development. Thus, propagation protocols should be developed before expanding the species use.

Seeds of T. capitatum have low (less than $40 \%$ ) germination capacity (Luna and Moreno, 2009; Luna et al., 2007; Moreira et al., 2010; Romão and Escudero, 2005) and appears to be nondependent on factors that may change with fire, such as heat and smoke (Luna et al., 2007; Moreira et al., 2010), increased light and soil nitrate (Luna and Moreno, 2009) for germination, while there is no report found in the literature about the effect of temperature, photoperiod, or cold stratification and mechanical scarification pretreatments on its germination. Similarly, T. polium has low seed germination (Nadjafi et al., 2006). The latter, being an endangered species in many countries of the Middle East, where it is widely used in traditional medicine, has been studied as for its possibility for in vitro propagation from ex vitro axillary buds (Al-Qudah et al., 2011) and cryopreservation (Rabba'a et al., 2012). It has also been reported that micropropagation of the ornamental medicinal Teucrium fruticans from shoot-tip explants (Frabetti et al., 2009) and of the medicinal Teucrium stocksianum from hypocotyl explants excised from seedlings germinated in vitro (Bouhouche and Ksiksi, 2007).

To facilitate the use of $T$. capitatum as a medicinal and ornamental plant, an efficient propagation protocol should be developed. Propagation by cuttings from native plants would apply extra pressure to wild populations and is limited to certain periods of the year when this species roots satisfactorily (Papafotiou et al., 2013). Neither propagation by seed would be satisfactory, because of the low germination ability. Micropropagation is appropriate for species that cannot be efficiently propagated by conventional horticultural techniques and an important tool to select, multiply, and conserve the critical 
genotypes of medicinal plants in particular (Debnath et al., 2006; Tripathi and Tripathi, 2003). Various medicinal plants and plants of Lamiaceae family in particular have been cloned through micropropagation protocols (Aicha et al., 2013; Chaturvedi et al., 2007; Debnath et al., 2006; Gonçalves and Romano, 2013; Santoro et al., 2013; Shtereva et al., 2015; Zuzarte et al., 2010). Moreover, germination of seeds in some species, which show low or no germination using conventional techniques, due to dormancy or specific germination requirements, could be greatly increased using in vitro methods (Fay, 1994).

In the present study, seed germination and clonal propagation of the species were investigated in vitro. Seed pretreatments, such as cold stratification, mechanical and chemical scarification, and incubation conditions, such as temperature and light, as well as storage period, were investigated as for their effect on germination. Moreover, micropropagation of the species was studied using explants of different origin (seedlings grown in vitro, mature, native, and greenhouse plants) for culture establishment, testing various cytokinins for shoot growth and proliferation, as well as examining various IBA concentrations and culture times for root induction, to develop an efficient micropropagation protocol for commercial use.

\section{Materials and Methods}

In vitro seed germination. Seeds were collected in Aug. 2012 from selected T. capitatum wild plants in the region of "Diomedes Botanic Garden" (38 00'39.24' 'B, $23^{\circ} 38^{\prime} 11.32^{\prime \prime} \mathrm{E}$, altitude $157 \mathrm{~m}$ ) in Haidari, a western suburb of Athens, Greece, and were stored at room temperature. Two months after harvesting, they were surface sterilized by $15 \% \mathrm{v} / \mathrm{v}$ commercial bleach $(4.5 \% \mathrm{w} / \mathrm{v}$ sodium hypochloride) water solution with one to two drops of Tween 20 (polyxyethylenesorbitan monolaurate, Merck $\mathrm{KGaA}$, Darmstadt, Germany) for 15 min followed by three 3-min rinses with sterile distilled water and were cultured for germination in vitro, in petri dishes, with $1 / 2$ MS medium (Murashige and Skoog, 1962) with $20 \mathrm{~g} \cdot \mathrm{L}^{-1}$ sucrose, at 5, $10,15,20$, and $25^{\circ} \mathrm{C}$ and $16-\mathrm{h}$ cool white fluorescent light $\left(37.5 \mu \mathrm{mol} \cdot \mathrm{m}^{-2} \cdot \mathrm{s}^{-1}\right) / 8$-h dark photoperiod. Stratification for 2 or 3 months at $5^{\circ} \mathrm{C}$, before culture at the above temperatures (excluding $5{ }^{\circ} \mathrm{C}$ ) was also tested.

Seeds were also collected in Aug. 2013 from the same wild plants and stored at room temperature. Three months after harvesting, seeds were scarified either using sandpaper (suitable for metal surfaces) for $1 \mathrm{~min}$ or by dipping in concentrated $\mathrm{H}_{2} \mathrm{SO}_{4}(>95 \%$, Fisher Scientific, Loughborough, UK) for $15 \mathrm{~min}$, or they did not receive any treatment (control), before surface sterilization by $15 \%$ $\mathrm{v} / \mathrm{v}$ commercial bleach solution for $15 \mathrm{~min}$ and culture for germination in vitro in petri dishes with $1 / 2$ MS medium, at $5,10,15,20$, and $25^{\circ} \mathrm{C}$ and 16 -h photoperiod (as above). In another experiment, 7 months after harvesting, seeds received various treatments: 1) scarification using sandpaper (as above) for 2 or 4 min, 2) dipping in concentrated $\mathrm{H}_{2} \mathrm{SO}_{4}$ for 15,17 , or $20 \mathrm{~min}, 3)$ dipping in boiling water $\left(100^{\circ} \mathrm{C}\right)$ for 1 or $5 \mathrm{~min}$, and 4) no treatment (control), before surface sterilization and culture for germination in vitro in petri dishes with $1 / 2$ MS medium, at 20 and $25{ }^{\circ} \mathrm{C}$ and 16-h photoperiod (as above). Twelve months after harvesting, seeds either did not receive any treatment or they were scarified by dipping in concentrated $\mathrm{H}_{2} \mathrm{SO}_{4}$ for $20 \mathrm{~min}$, before surface sterilization and culture for germination in vitro, in petri dishes with $1 / 2$ MS medium, at 5, 10, 15, 20, 25 , and $30{ }^{\circ} \mathrm{C}$ and 16 -h photoperiod (as above) or continuous darkness.

The observation period was 3 months, except of the last experiment held after 12 months of seed storage, which was lasted for 2 months. Five replicates of 20 seeds were used for each treatment and a seed was considered germinated when the radicle was longer than $1 \mathrm{~mm}$. $\mathrm{T}_{50}$ was also estimated, which is the time needed for $50 \%$ of the final germination value, and it is calculated by linear interpolation from the two germination values closest to median germination.

In vitro culture establishment and multiplication. Seedlings that were germinated in vitro were transferred on MS medium with $30 \mathrm{~g} \cdot \mathrm{L}^{-1}$ sucrose for 6 weeks to grow and be used as explant source for the establishment of in vitro cultures. Singlenode shoot segments, $\approx 1.0 \mathrm{~cm}$ long, were used as explants and were cultured initially on MS medium with $30 \mathrm{~g} \cdot \mathrm{L}^{-1}$ sucrose and 0.5 , 1.0 , or $2.0 \mathrm{mg} \cdot \mathrm{L}^{-1} \mathrm{BA}$ (first establishment experiment). A number of subcultures on MS medium with $1.0 \mathrm{mg} \cdot \mathrm{L}^{-1} \mathrm{BA}$ followed.

To clarify whether the growth habit of seedlings (mother plants) affected explant response to in vitro culture, seedlings germinated in vitro were transferred on MS medium to grow for 6 weeks and then single-node explants were excised either from seedlings that formed many axillary shoots (branched seedlings) or from those that formed only one main shoot (unbranched seedlings). These explants were initially cultured on MS medium with $0.0,0.5,1.0$, or $2.0 \mathrm{mg} \cdot \mathrm{L}^{-1} \mathrm{BA}$ (second establishment experiment), followed by four subcultures on MS medium with $1.0 \mathrm{mg} \cdot \mathrm{L}^{-1} \mathrm{BA}$. In each stage, data were recorded separately for explants derived from branched or unbranched seedlings.

Explants for the establishment of in vitro culture were also excised from mature wild plants (grown in the region where seeds were collected), once in spring (April), from various positions upon the shoot (apical, top, and middle), and two times in summer (June and August), from the apical part of the shoot. Apart from apical explants, all the others were of single node. Before explant excision, mother material was washed in water with light detergent for $10 \mathrm{~min}$ under stirring, rinsed under running tap water for $10 \mathrm{~s}$, and surface sterilized with $30 \% \mathrm{v} / \mathrm{v}$ commercial bleach water solution with one to two drops of Tween 20 for $10 \mathrm{~min}$ followed by three 3-min rinses with sterile distilled water. The explants were cultured on MS medium with $1.0 \mathrm{mg} \cdot \mathrm{L}^{-1} \mathrm{BA}$.

Moreover, explants were excised in June from the apical and top part of shoots derived from 5-month old plantlets, produced by cuttings from mature wild plants, and grown inside a heated greenhouse. The sterilization procedure was as described above, with the difference that $15 \% \mathrm{v} / \mathrm{v}$ commercial bleach solution was used. The explants were cultured on MS medium either without plant growth regulators (control) or with $1.0 \mathrm{mg} \cdot \mathrm{L}^{-1}$ BA or zeatin. Seven months later, in January, explants were again collected from the same greenhouse-grown plants, were surface sterilized, following the same procedure, with $30 \% \mathrm{v} / \mathrm{v}$ bleach solution and were cultured either on control or on MS medium with $0.5,1.0$, or $2.0 \mathrm{mg} \cdot \mathrm{L}^{-1} \mathrm{BA}$.

The effect of various cytokinin types on shoot proliferation was tested, using singlenode explants, $0.6 \mathrm{~cm}$ long, excised from a culture established from in vitro-grown seedlings, during the eighth subculture on MS medium with $1.0 \mathrm{mg} \cdot \mathrm{L}^{-1} \mathrm{BA}$. The explants were cultured on MS medium containing $0.0,0.5,1.0,2.0$, or $4.0 \mathrm{~g} \cdot \mathrm{L}^{-1} \mathrm{BA}$ or zeatin or kinetin or $2 \mathrm{iP}$.

Three replicates of 15 explants were used for each treatment. Data were collected after $40 \mathrm{~d}$ of culture. The "multiplication index" of each culture was calculated by multiplying the percentage of explants that produced shoots by the mean number of shoots per responding explant, and by the mean length of produced shoots, divided by 0.6 , which was the length of explants used for subculture. The "multiplication index" gave the proliferation potential of each culture by showing the number of explants that the culture could provide for a subsequent subculture.

Root induction and acclimatization. Microshoots, $1.0-2.0 \mathrm{~cm}$ long, produced in the first culture established from in vitrogrown seedlings, during the first until the fifth subculture, were cultured for root induction on $1 / 2$ MS medium with various IBA concentrations $\left(0.0,0.5,1.0,2.0\right.$, or $\left.4.0 \mathrm{mg} \cdot \mathrm{L}^{-1}\right)$ either continuously for 5 weeks or for 1 week followed by transfer to $1 / 2$ MS medium without plant growth regulators for four more weeks. Twenty-five microshoots were used for each treatment, and data were collected after $35 \mathrm{~d}$ of culture.

For acclimatization, plantlets were transferred ex vitro into trays (eight plantlets per $500-\mathrm{mL}$ volume tray) with a mixture of peat: perlite $(1: 1, \mathrm{v} / \mathrm{v})$. The trays were covered with plastic wrap (SANITAS; Sarantis S.A., Marousi, Greece) and placed in a growth chamber $\left(20^{\circ} \mathrm{C}\right.$ and $16-\mathrm{h}$ cool white fluorescent light $37.5 \mu \mathrm{mol} \cdot \mathrm{m}^{-2} \cdot \mathrm{s}^{-1}$ ) for 1 week before their transfer to a heated greenhouse. Three replicates of 15 rooted microshoots were used and their survival was estimated at $40 \mathrm{~d}$ after transfer to the greenhouse. Subsequently, plantlets were transplanted individually in plastic pots on a mixture of peat: perlite 
$(2: 1, v / v)$ and were fertilized per $45 \mathrm{~d}$ with $2 \mathrm{~g} \cdot \mathrm{L}^{-1}$ soluble fertilizer (Nutrileaf 60, 20-20 20; Miller Chemical and Fertilizer Corp., Hanover, PA), $100 \mathrm{~mL}$ of solution per pot.

In vitro culture conditions. All culture media were solidified with $8 \mathrm{~g} \cdot \mathrm{L}^{-1}$ agar and their $\mathrm{pH}$ was adjusted to 5.7 before addition of the agar and autoclaving at $121{ }^{\circ} \mathrm{C}$ for $20 \mathrm{~min}$. Initial culture took place in test tubes $(25 \times 100 \mathrm{~mm})$ with $10 \mathrm{~mL}$ medium, while subculture and rooting took place in $75-\mathrm{mL}$ glass vessels with $20 \mathrm{~mL}$ medium (three explants and five microshoots per vessel, respectively), all of them covered with plastic wrap. All in vitro cultures were maintained at $25{ }^{\circ} \mathrm{C}$ with a 16-h photoperiod at $37.5 \mu \mathrm{mol} \cdot \mathrm{m}^{-2} \cdot \mathrm{s}^{-1}$ provided by cool-white fluorescent lamps.

Statistical analysis. The completely randomized design was used in all experiments. The significance of the results was tested by one- or two-way analysis of variance and the means of the treatments were compared by the Student's $t$ test at $P \leq 0.05$ (JMP software; SAS Institute, Cary, NC). The data on percentage were statistically analyzed after arcsine transformation. The SE of the mean of each treatment was calculated.

\section{Results and Discussion}

In vitro seed germination. Two months after harvesting and storage at room temperature, the effect of cold stratification on seed germination was studied. Unstratified seeds germinated at extremely low percentages (lower than 3\%) at a temperature range from 10 to $20^{\circ} \mathrm{C}$, while no seed germinated at 5 or $25{ }^{\circ} \mathrm{C}$. Equally low germination percentages of $T$. capitatum seeds have also been reported by Luna et al. (2007) and Luna and Moreno (2009). Cold stratification for 2 or 3 months did not have a significant effect on seed germination, as the maximum germination observed was $7.9 \%$ at $25{ }^{\circ} \mathrm{C}$ for seeds stratified for 3 months (data not shown). Seed germination generally proceeded slowly, starting after 1 month of incubation and continuing until the end of the 3rd month (end of the experiment).

After 3 months of storage, the effect of mechanical and chemical scarification, along with temperature, on seed germination was examined. Seeds were scarified by dipping in concentrated $\mathrm{H}_{2} \mathrm{SO}_{4}$ for $15 \mathrm{~min}$ and incubated at $25{ }^{\circ} \mathrm{C}$ germinated at the highest percentage $(36 \%)$, followed by those that received the same pretreatment and were incubated at 15 or $20{ }^{\circ} \mathrm{C}(22 \%$ and $24 \%$ germination, respectively), while lower germination percentages were observed at 10 or $5{ }^{\circ} \mathrm{C}$ (Table 1). Mechanical scarification with sandpaper for $1 \mathrm{~min}$ was ineffective, inducing germination percentages equally low to those recorded by unscarified seeds, while no seed germinated at 5 or $10{ }^{\circ} \mathrm{C}$ (Table 2). The positive effect of acid scarification on germination indicates coat-imposed dormancy. Similarly, in $T$. polium seeds, the hard seedcoat was considered as the main inhibitor of germination, as acid scarification by $\mathrm{H}_{2} \mathrm{SO}_{4}$
$(75 \% \mathrm{v} / \mathrm{v})$ for $10 \mathrm{~min}$ or for $5 \mathrm{~min}$ combined with soaking in $1500 \mathrm{mg} \cdot \mathrm{L}^{-1}$ gibberellic acid $\left(\mathrm{GA}_{3}\right)$ for $48 \mathrm{~h}$, also broke dormancy and induced $32 \%$ and $34 \%$ germination, respectively (Nadjafi et al., 2006). Coat-imposed dormancy is caused by either the impermeability of the coat to water and/or gases, the mechanical prevention of radicle extension, or the seedcoat, which may prevent inhibitory substances from leaving the embryo or supply inhibitors to the embryo, while the occurrence of polymorphism in species, which exhibit coat dormancy usually allows for a small percentage of seeds to be readily permeable (Kelly et al., 1992). The ecological significance of impermeable seed includes the ability to rapidly recolonize burnt area after fire and to withstand ingestion by animals and birds (Rolston, 1978).

Seven months after harvesting, scarification for longer time, as well as dipping in boiling water for two dipping times were tested. Increasing dipping time in concentrated $\mathrm{H}_{2} \mathrm{SO}_{4}$ from 15 to 20 min significantly increased germination percentage of seeds (Table 2). Increasing duration of scarification with sandpaper from 2 to $4 \mathrm{~min}$ did not improve seed germination percentage, which was still similar to that recorded by unpretreated seeds (Table 2). No seed dipped in boiling water for 1 or $5 \mathrm{~min}$ germinated (Table 2), which was also observed in $T$. polium (Nadjafi et al., 2006). Previous reports on heat pretreatments, which consisted of exposure of $T$. capitatum seeds to 80 or $100{ }^{\circ} \mathrm{C}$ for 5 or $10 \mathrm{~min}$ inside an electric oven, had equivocal results; Moreira et al. (2010) recorded germination percentages from $22 \%$ to $39 \%$, while Luna et al. (2007) found extremely low germination percentages lower than $4 \%$.

Twelve months after harvesting, the effect of scarification, temperature, and photoperiod on seed germination was examined. As in the previous experiment, seeds scarified by dipping in concentrated $\mathrm{H}_{2} \mathrm{SO}_{4}$ for $20 \mathrm{~min}$ germinated at significantly higher percentage and reached $\mathrm{T}_{50}$ faster than unscarified seeds, which once more germinated at very low percentage (Table 3). As regard temperature, the highest seed germination percentages were observed at $25^{\circ} \mathrm{C}$, followed by 15 and $20{ }^{\circ} \mathrm{C}$, while at $30{ }^{\circ} \mathrm{C}$, not only fewer seeds germinated but seedlings were dehydrated too (Table 3). No seed germinated at $5{ }^{\circ} \mathrm{C}$, while at $10{ }^{\circ} \mathrm{C}$, only scarified seeds germinated at extremely low percentage (Table 3 ). Similar temperature requirements have been shown for other Mediterranean xerophytes, $20-25{ }^{\circ} \mathrm{C}$ for Sideritis athoa (Papafotiou and Kalantzis, 2009b) and Sideritis syriaca L. ssp. syriaca (Thanos and Doussi, 1995), $20{ }^{\circ} \mathrm{C}$ for Anthyllis barba-jovis (Morbidoni et al., 2008), $15-20{ }^{\circ} \mathrm{C}$ for Coridothymus capitatus, Origanum vulgare subsp. Hirtum, and Satureja thymbra (Thanos et al., 1995), $15{ }^{\circ} \mathrm{C}$ for Dianthus fruticosus (Papafotiou

Table 1. The effect of scarification pretreatment and incubation temperature on in vitro germination of Teucrium capitatum seeds, 3 mo. after harvesting and storage at room temperature.

\begin{tabular}{lcccc}
\hline Pretreatment & $\begin{array}{c}\text { Germination } \\
\text { temp }\left({ }^{\circ} \mathrm{C}\right)\end{array}$ & Germination $(\%)$ & $\mathrm{T}_{50}$ & $\begin{array}{c}\text { Time }(\mathrm{d}) \text { for } \\
\text { full germination }\end{array}$ \\
\hline Without scarification & 5 & $0.0 \pm 0.0 \mathrm{e}^{\mathrm{z}}$ & - & - \\
& 10 & $0.0 \pm 0.0 \mathrm{e}$ & - & 64 \\
& 15 & $10.0 \pm 3.2 \mathrm{~cd}$ & 50 & - \\
& 20 & $0.0 \pm 0.0 \mathrm{e}$ & - & 60 \\
Scarification with sand & 25 & $4.0 \pm 2.4 \mathrm{de}$ & - & - \\
paper for 1 min & 5 & $0.0 \pm 0.0 \mathrm{e}$ & - & 66 \\
& 10 & $0.0 \pm 0.0 \mathrm{e}$ & 42 & 46 \\
Scarification by dipping in & 15 & $8.0 \pm 3.7 \mathrm{de}$ & 30 & 68 \\
concentrated sulfuric acid & 20 & $17.0 \pm 3.7 \mathrm{bc}$ & 68 & 66 \\
for 15 min & 25 & $4.0 \pm 2.4 \mathrm{de}$ & 30 & 90 \\
& 5 & $2.0 \pm 2.0 \mathrm{de}$ & 30 & 56
\end{tabular}

${ }^{\mathrm{z}}$ Mean $( \pm \mathrm{SE})$ separation in columns by Student's $t$ test at $P \leq 0.05$.

** Significant at $P \leq 0.01$.

Table 2. The effect of various pretreatments on in vitro germination of Teucrium capitatum seeds, which were incubated at 20 and $25^{\circ} \mathrm{C}$ (data shown together), 7 mo. after harvesting and storage at room temperature.

\begin{tabular}{lccc}
\hline Pretreatment & Germination $(\%)$ & $T_{50}$ & Time $(\mathrm{d})$ for full germination \\
\hline Without pretreatment & $9.7 \pm 3.0 \mathrm{c}^{\mathrm{z}}$ & 48 & 80 \\
$\mathrm{H}_{2} \mathrm{SO}_{4}$ for $15 \mathrm{~min}$ & $13.5 \pm 2.8 \mathrm{bc}$ & 30 & 80 \\
$\mathrm{H}_{2} \mathrm{SO}_{4}$ for $17 \mathrm{~min}$ & $20.0 \pm 3.5 \mathrm{ab}$ & 22 & 68 \\
$\mathrm{H}_{2} \mathrm{SO}_{4}$ for $20 \mathrm{~min}$ & $26.5 \pm 3.0 \mathrm{a}$ & 22 & 50 \\
Mechanical scarification for 2 min & $2.0 \pm 1.3 \mathrm{de}$ & 50 & 68 \\
Mechanical scarification for 4 min & $8.3 \pm 2.9 \mathrm{~cd}$ & 42 & - \\
Boiling water for 1 min & $0.0 \pm 0.0 \mathrm{e}$ & - & - \\
Boiling water for 5 min & $0.0 \pm 0.0 \mathrm{e}$ & - & \\
\hline
\end{tabular}

$\mathrm{H}_{2} \mathrm{SO}_{4}=$ sulfuric acid.

${ }^{\text {zMean }}( \pm \mathrm{SE})$ separation in columns by Student's $t$ test at $P \leq 0.05$. 
Table 3. The effect of acid scarification pretreatment, incubation temperature, and photoperiod on in vitro germination of Teucrium capitatum seeds, 12 mo. after harvesting and storage at room temperature.

\begin{tabular}{|c|c|c|c|c|c|}
\hline Pretreatment & Photoperiod & Germination temp $\left({ }^{\circ} \mathrm{C}\right)$ & Germination (\%) & $\mathrm{T}_{50}$ & Time (d) for full germination \\
\hline \multirow[t]{12}{*}{ Without scarification } & $16 \mathrm{~h}$ light $/ 8 \mathrm{~h}$ dark & 5 & $0.0 \pm 0.0 \mathrm{f}^{z}$ & - & - \\
\hline & & 10 & $0.0 \pm 0.0 \mathrm{f}$ & - & - \\
\hline & & 15 & $5.0 \pm 2.2 \mathrm{ef}$ & 44 & 48 \\
\hline & & 20 & $1.1 \pm 1.1 \mathrm{ef}$ & 16 & 16 \\
\hline & & 25 & $6.0 \pm 2.7 \mathrm{de}$ & 22 & 60 \\
\hline & & 30 & $1.0 \pm 1.0 \mathrm{ef}$ & 60 & 60 \\
\hline & Continuous darkness & 5 & $0.0 \pm 0.0 \mathrm{f}$ & - & - \\
\hline & & 10 & $0.0 \pm 0.0 \mathrm{f}$ & - & - \\
\hline & & 15 & $4.0 \pm 2.2 \mathrm{ef}$ & 34 & 60 \\
\hline & & 20 & $6.7 \pm 2.9 \mathrm{de}$ & 38 & 60 \\
\hline & & 25 & $1.0 \pm 1.0 \mathrm{ef}$ & 30 & 30 \\
\hline & & 30 & $2.2 \pm 1.5 \mathrm{ef}$ & 24 & 28 \\
\hline \multirow{12}{*}{$\begin{array}{l}\text { Scarification by dipping in concentrated } \\
\text { sulfuric acid for } 20 \mathrm{~min}\end{array}$} & $16 \mathrm{~h}$ light $/ 8 \mathrm{~h}$ dark & 5 & $0.0 \pm 0.0 \mathrm{f}$ & - & - \\
\hline & & 10 & $9.0 \pm 3.8 \mathrm{~d}$ & 38 & 60 \\
\hline & & 15 & $28.0 \pm 5.3 \mathrm{a}$ & 28 & 60 \\
\hline & & 20 & $28.2 \pm 4.1 \mathrm{a}$ & 18 & 60 \\
\hline & & 25 & $33.3 \pm 4.8 \mathrm{a}$ & 18 & 60 \\
\hline & & 30 & $16.0 \pm 2.7 \mathrm{c}$ & 18 & 60 \\
\hline & Continuous darkness & 5 & $0.0 \pm 0.0 \mathrm{f}$ & - & - \\
\hline & & 10 & $3.0 \pm 2.1 \mathrm{ef}$ & 28 & 60 \\
\hline & & 15 & $17.0 \pm 5.2 \mathrm{bc}$ & 30 & 60 \\
\hline & & 20 & $22.6 \pm 3.4 b$ & 16 & 60 \\
\hline & & 25 & $32.0 \pm 4.7 \mathrm{a}$ & 16 & 24 \\
\hline & & 30 & $12.0 \pm 2.5 \mathrm{~cd}$ & 16 & 60 \\
\hline $\mathrm{F}_{\text {pretreatment }}$ & & & - & & \\
\hline$F_{\text {photoperiod }}$ & & & NS & & \\
\hline$F_{\text {temperature }}$ & & & - & & \\
\hline $\mathrm{F}_{\text {pretreatment }} \times$ photoperiod & & & NS & & \\
\hline $\mathrm{F}_{\text {photoperiod }} \times$ temperature & & & NS & & \\
\hline $\mathrm{F}_{\text {pretreatment }} \times$ temperature & & & $* *$ & & \\
\hline $\mathrm{F}_{\text {pretreatment }} \times$ photoperiod $\times$ temperature & & & NS & & \\
\hline
\end{tabular}

${ }^{\mathrm{z}}$ Mean $( \pm \mathrm{SE})$ separation in columns by Student's $t$ test at $P \leq 0.05$.

NS, **Nonsignificant or significant at $P \leq 0.01$, respectively.

and Stragas, 2009) and Globularia alypum (Bertsouklis and Papafotiou, 2010), and 10 $20{ }^{\circ} \mathrm{C}$ for Origanum dictamnus, Salvia pomifera L. ssp. pomifera, and Salvia fruticosa (Thanos and Doussi, 1995).

Photoperiod had no significant effect on seed germination (Table 3). Regarding seed germination of other Mediterranean-endemic aromatic plants, C. capitatus was light indifferent, O. vulgare subsp. hirtum had an absolute light requirement, while in $S$. thymbra, a proportion of the seeds germinated in the dark (Thanos et al., 1995). Other endemic Labiates of Crete, such as $O$. dictamnus, $S$. syriaca ssp. syriaca, S. pomifera ssp. Pomifera, and $S$. fruticosa, showed an intermediate response toward light, as a result of their intermediate levels of active phytochrome maintained in darkness; seed germination was partially manifested in darkness but it was significantly enhanced (particularly at suboptimal temperatures) by white or red light, while illumination with far-red light (simulating light conditions under canopy) resulted in significant inhibition compared with dark controls (Thanos and Doussi, 1995).

One year after harvesting and storage at room temperature, seeds not only had not lost their germination ability, but germinated somehow faster $\left(\mathrm{T}_{50}\right.$ of unpretreated seeds being $16-44 \mathrm{~d}$ at $15-25{ }^{\circ} \mathrm{C}$, Table 3 ) than seeds put for germination after 2 months of storage $\left(\mathrm{T}_{50}=40-72 \mathrm{~d}\right.$, data not shown). Also age of seeds positively affected germination of other Labiates, in which old seeds germinated at a higher percentage than fresh ones, as already observed by Theophrastus, possibly as a result of the volatilization of essential oils present on the nutlet coat (Thanos et al., 1995).

In vitro culture establishment and multiplication. During the first establishment experiment from in vitro-grown seedlings, explants gave shoots at high percentages $(80 \%$ to $87 \%)$ at all BA concentrations $(0.5$, 1.0, and $2.0 \mathrm{mg} \cdot \mathrm{L}^{-1}$ ) used (data not shown), similarly to other Mediterranean xerophytes, as $S$. athoa and Lithodora zahnii, whose in vitro cultures were also established from seedlings at very high percentages on MS medium supplemented with low (0.2-1.0 $\mathrm{mg} \cdot \mathrm{L}^{-1}$ ) BA concentration (Papafotiou and Kalantzis, 2009a, 2009b). More axillary shoots per explant $(13 \pm 0.7)$ were formed in the medium with $2.0 \mathrm{mg} \cdot \mathrm{L}^{-1}$ BA compared to media with lower $\mathrm{BA}$ concentration $\left(6 \pm 0.6\right.$ in $0.5 \mathrm{mg} \cdot \mathrm{L}^{-1} \mathrm{BA}$ and $9 \pm 0.7$ in $1.0 \mathrm{mg} \cdot \mathrm{L}^{-1} \mathrm{BA}$ ), while the length of produced shoots was higher in the medium with the lowest $\left(0.5 \mathrm{mg} \cdot \mathrm{L}^{-1}\right)$ BA concentration $(1.7 \pm$ $0.2 \mathrm{~cm}$ vs. $1.0 \pm 0.1 \mathrm{~cm}$ and $0.7 \pm 0.1 \mathrm{~cm}$ in 1.0 and $2.0 \mathrm{mg} \cdot \mathrm{L}^{-1} \mathrm{BA}$, respectively). During subsequent subcultures on a medium with $1.0 \mathrm{mg} \cdot \mathrm{L}^{-1} \mathrm{BA}$, which was selected because it gave satisfactory both shoot number and shoot length (i.e., high multiplication index), 7.6 shoots per explant on average were produced averaging $1.4 \mathrm{~cm}$ long, but a strong variance of explant response was observed. Thus, some explants produced a few long shoots and others numerous shorter shoots
(Fig. 1A), resembling the growth habit of seedlings (Fig. 1B) that were used as mother plants. Variation in explant response was eliminated as subcultures were going on and explants with high shoot multiplication rate were chosen. According to Marks and Myers (1994), decisions taken during choice of shoot types in vitro and their manipulation during subculture may affect following performance and uniformity of micropropagated plants. Shoot types or shoot segments with different growth potential should be subcultured separately and uniform treatments should be applied to reduce variability of micropropagated plants.

During the second establishment experiment from in vitro-grown seedlings, the effect of seedling growth habit on the response of excised explants was examined. Explants excised from branched seedlings and cultured with $0.5-2.0 \mathrm{mg} \cdot \mathrm{L}^{-1} \mathrm{BA}$ formed shoots at higher percentages than those cultured on a hormone-free (HF) medium, while the opposite was observed in explants excised from unbranched seedlings (Table 4). Explants excised from branched seedlings formed shoots at significantly higher percentages than explants excised from unbranched ones, when they were cultured on a medium supplemented with BA, while no difference was observed between the two types of explant, when they were cultured on a medium without BA (Table 4). More shoots per explant were formed on media containing BA compared with HF medium, while the opposite was observed with shoot length, which 

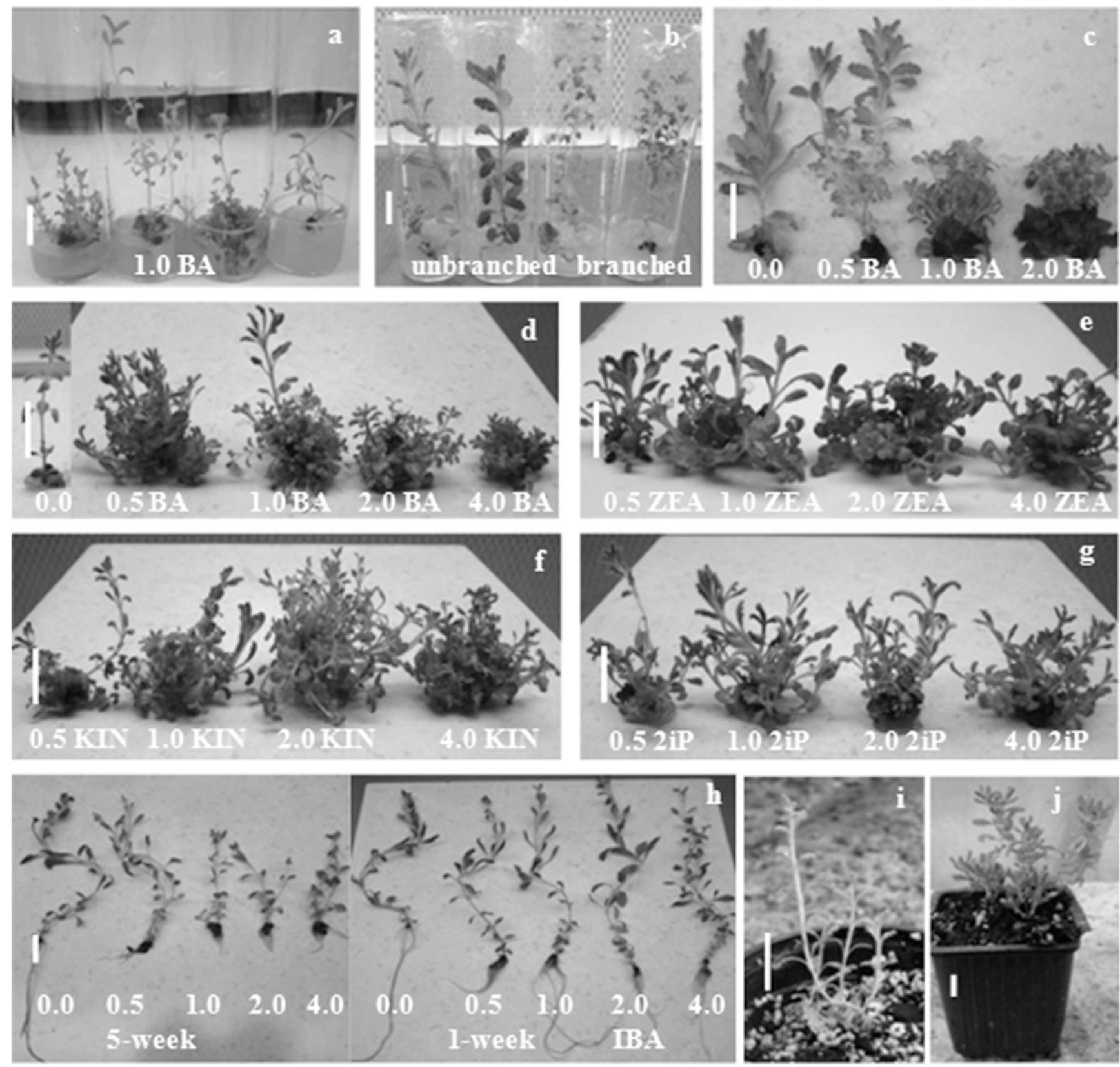

Fig. 1. (A) Variation in the response of Teucrium capitatum explants excised from seedlings and cultured on Murashige and Skoog (1962) growth medium (MS) with $1.0 \mathrm{mg} \cdot \mathrm{L}^{-1}$ 6-benzyladenine (BA), (B) growth habit of seedlings grown in vitro on hormone-free (HF)-MS medium for 6 weeks, and (C) typical response of explants excised from unbranched seedlings and cultured on MS medium with marked BA concentration (mg. $\left.\mathrm{L}^{-1}\right)$. Characteristic shoot production at the multiplication stage from nodal explants cultured on MS medium supplemented with (D) BA, (E) zeatin, (F) kinetin, and (G) 6- $\gamma-\gamma-($ dimethylallylamino)purine $(2 \mathrm{iP})$ at marked concentrations $\left(\mathrm{mg} \cdot \mathrm{L}^{-1}\right)$, typical rooting of microshoots cultured on half-strength $(1 / 2)$ MS medium supplemented with marked indole-3butyric acid (IBA) concentrations ( $\mathrm{mg} \cdot \mathrm{L}^{-1}$ ), either continuously for 5 weeks or only for 1 week followed by transfer to HF-1/2MS medium for (H) 4 more weeks and acclimatized plantlet (I) 3 and (J) 4 months after its ex vitro transfer. Size bars $=1.0 \mathrm{~cm}$.

was greater in HF medium than in a BA containing medium (Table 4; Fig. 1C). Explants excised from branched seedlings and cultured on a medium with $0.5 \mathrm{mg} \cdot \mathrm{L}^{-1} \mathrm{BA}$ presented the highest multiplication index (Table 4).

The effect of seedling type on shooting was so strong that even after two subsequent subcultures on MS medium with $1.0 \mathrm{mg} \cdot \mathrm{L}^{-1}$ $\mathrm{BA}$, explants taken from cultures initiated from branched seedlings responded at higher percentage, gave more and longer shoots and therefore higher multiplication index than explants from cultures derived from unbranched seedlings (Table 5). It was confirmed that seedling growth habit not only affects explant ability to initiate in vitro culture, but also its ability for shoot multiplication. After four subcultures, differences between the two types of explant had been lessened, but still more shoots were produced by explants excised from branched seedlings (Table 5). Bud growth and further development in vitro has been shown to be dictated by bud topophysis, and in some cases by the potential growth habit of shoots on the stock plant (Marks and Myers, 1992). Buds on shoots growing in vitro also express differential growth potential paralleling that of the original explant selection. In Daphne, this growth potential not only affected shoot multiplication and rooting, but also the branching habit of the micropropagated plant ex vitro (Marks and Myers, 1992). In apple rootstock M.9 too, culture lines of shoots coming from different explants steadily showed different shoot multiplication rate and rooting ability (Webster and Jones, 1989).

Almost all cultures derived from explants collected from adult wild plants in spring (excluding $20 \%$ of apical explants), as well as 
Table 4. Effect of growth habit of Teucrium capitatum seedlings used for explant source and of medium 6-benzyladenine (BA) concentration on shoot production at in vitro establishment stage.

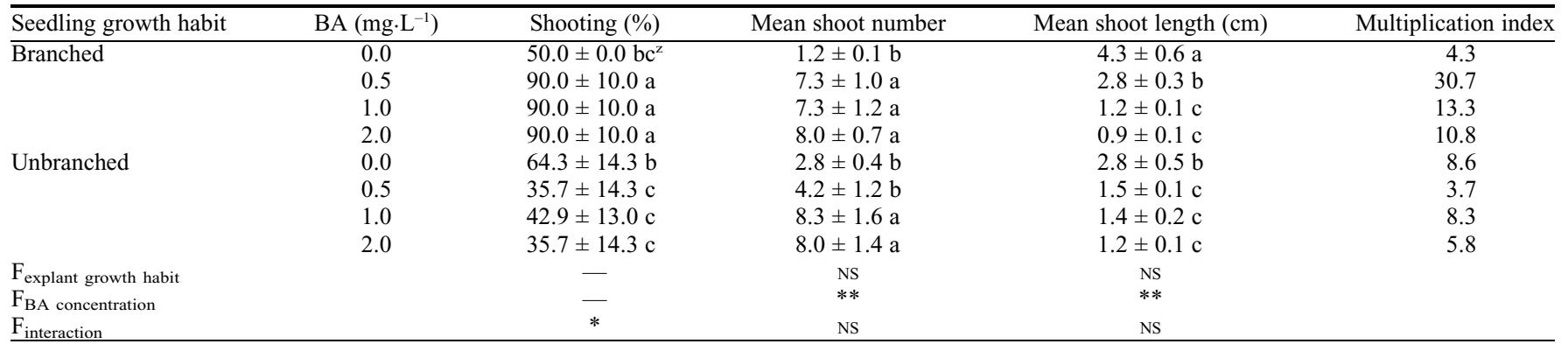

${ }^{\mathrm{z}}$ Mean $( \pm \mathrm{SE})$ separation in columns by Student's $t$ test at $P \leq 0.05$.

Ns, ***Nonsignificant or significant at $P \leq 0.05$ or $P \leq 0.01$, respectively.

Multiplication index $=$ shooting $(\%) \times$ mean shoot number per explant $\times$ mean shoot length $/ 0.6$.

Table 5. Effect of growth habit of Teucrium capitatum seedlings used for explant source at the in vitro establishment stage on shoot production at subsequent multiplication stage.

\begin{tabular}{|c|c|c|c|c|c|}
\hline Subculture & Seedling growth habit & Shooting (\%) & Mean shoot number & Mean shoot length $(\mathrm{cm})$ & Multiplication index \\
\hline \multirow[t]{2}{*}{ Subculture 1} & Branched & $93.3 \pm 2.8 \mathrm{a}^{\mathrm{z}}$ & $11.5 \pm 0.9 \mathrm{a}$ & $2.4 \pm 0.2 \mathrm{a}$ & 42.6 \\
\hline & Unbranched & $80.0 \pm 4.9 \mathrm{a}$ & $7.6 \pm 0.7 \mathrm{~b}$ & $1.8 \pm 0.2 b$ & 30.7 \\
\hline \multirow[t]{2}{*}{ Subculture 2} & Branched & $100.0 \pm 0.0 \mathrm{a}$ & $15.4 \pm 1.1 \mathrm{a}$ & $2.6 \pm 0.1 \mathrm{a}$ & 67.2 \\
\hline & Unbranched & $80.0 \pm 4.9 \mathrm{~b}$ & $9.2 \pm 1.0 \mathrm{~b}$ & $2.1 \pm 0.1 \mathrm{~b}$ & 26.0 \\
\hline \multirow[t]{2}{*}{ Subculture 4} & Branched & $93.3 \pm 4.4 \mathrm{a}$ & $13.6 \pm 0.8 \mathrm{a}$ & $1.4 \pm 0.1 \mathrm{a}$ & 29.6 \\
\hline & Unbranched & $100.0 \pm 0.0 \mathrm{a}$ & $9.7 \pm 1.1 \mathrm{~b}$ & $1.7 \pm 0.1 \mathrm{a}$ & 27.5 \\
\hline
\end{tabular}

${ }^{\mathrm{z}}$ Mean $( \pm \mathrm{SE})$ separation in columns per each subculture by Student's $t$ test at $P \leq 0.05$.

Multiplication index $=$ shooting $(\%) \times$ mean shoot number per explant $\times$ mean shoot length/0.6.

$40 \%$ of the cultures derived from explants collected in summer were contaminated, while the noncontaminated explants did not show any response. Other Mediterranean aromatic xerophytes, as Rosmarinus officinalis, Lavandula latifolia, and Lavandula stoechas also presented difficulties in culture establishment from mature field-grown mother plants (Misra and Chaturvedi, 1984; Nobre, 1996; Sánchez-Gras and Calvo, 1996); shoot tip and nodal explants of R. officinalis turned brown within $7 \mathrm{~d}$ of incubation, excepting $10 \%$ of nodal explants, soaked in polyvinylpyrrolidone solution, which remained green and produced axillary shoots after $30 \mathrm{~d}$ (Misra and Chaturvedi, 1984). Explants excised from adult plants may generally present difficulties in culture because of restrictions in growth, their recalcitrant nature, high frequency of infections, high levels of polyphenols diffusion, hyperhydration, and low response level (Bonga, 1981; Zimmerman, 1986).

Although only $10 \%$ of explants collected from 5-month-old plants grown from cuttings in a greenhouse were contaminated, shoots were formed at low percentages $(13 \%$ to $25 \%$ ), irrespectively of the cytokinin supplementation of the medium (data not shown). However, significantly more shoots per explant $(6.6 \pm 1.0)$ were produced in a medium with BA compared with the HF medium $(1.4 \pm 1.4)$ and the zeatin supplemented one $(1.7 \pm 0.3)$, while shoot length was significantly higher in the medium with zeatin $(4.4 \pm 1.3 \mathrm{~cm})$ compared with the HF $(2.4 \pm$ $0.3 \mathrm{~cm})$ and the BA medium $(1.2 \pm 0.1 \mathrm{~cm})$.

Seedlings are the preferred material for use in initiation of cultures when the aim is plant conservation, due to the maximized genetic diversity of produced plants (Fay, 1994). For introduction of a native plant species as ornamental in natural landscapes, as this of an archaeological site, genetic diversity of plants is also desirable. However, when a plant is propagated for general ornamental use in the horticultural industry, or for medicinal use, it is preferable to use selected genotypes as mother plants rather than seedlings with unknown potential. The initiation of in vitro cultures from adult wild plants of T. capitatum was not successful, but this could be possibly overcome if an intermediate stage was inserted, that could possibly cause "rejuvenation" to tissue of explants (Ballester et al., 1990; Pierik, 1990) and also reduce contamination risk. Thus, plantlets of selected adult genotypes could be produced by cuttings, remain for growth inside a greenhouse and be used as explant source for culture initiation.

Shoot multiplication was affected both by cytokinin type and its concentration added to the medium. All explants produced shoots in all combinations tested, excepting $4.0 \mathrm{mg} \cdot \mathrm{L}^{-1}$ zeatin and 1.0 and $2.0 \mathrm{mg} \cdot \mathrm{L}^{-1} 2 \mathrm{iP}$, where a few explants did not respond (Table 6). Proliferation ranged from 3.9 to 15.0 shoots per explant depending on the cytokinin treatment, while in the HF medium, only 1.3 shoots per explant were produced (Fig. 1D-G). More shoots per explant (13.5-15.0) were produced when BA was used, irrespectively of its concentration, as well as with $4.0 \mathrm{mg} \cdot \mathrm{L}^{-1}$ kinetin (Table 6). The effective concentration for shoot production ranged from 0.5 to $4 \mathrm{mg} \cdot \mathrm{L}^{-1}$ for $\mathrm{BA}, 1.0$ to $4.0 \mathrm{mg} \cdot \mathrm{L}^{-1}$ for kinetin and $2 \mathrm{iP}$, and 2.0 to $4.0 \mathrm{mg} \cdot \mathrm{L}^{-1}$ for zeatin.

Explants were cultured on the HF medium formed the longest shoots, followed by those cultured on a medium containing $0.5 \mathrm{mg} \cdot \mathrm{L}^{-1}$ kinetin or zeatin or $1.0 \mathrm{mg} \cdot \mathrm{L}^{-1} 2 \mathrm{iP}$ (Table 6 ). Shoot length was decreasing by increasing cytokinin concentration (Table 6, Fig. 1D$\mathrm{G})$, as it has been previously reported for a number of plants (Martini and Papafotiou, 2013; Sahoo and Chand, 1998; Sarwar et al., 1998). The highest shoot multiplication index was recorded on media containing $0.5-2.0 \mathrm{mg} \cdot \mathrm{L}^{-1}$ $\mathrm{BA}$ or $1.0 \mathrm{mg} \cdot \mathrm{L}^{-1}$ kinetin or $2 \mathrm{iP}$ and the lowest in the HF medium (Table 6).

A necessity for cytokinin for high shoot multiplication rates was revealed. BA at a wide range of concentration $\left(0.5-2.0 \mathrm{mg} \cdot \mathrm{L}^{-1}\right)$ was more appropriate for shoot multiplication than kinetin or $2 \mathrm{iP}$, because it gave more shoots per explant and higher multiplication index, while zeatin was the least effective. Higher shoot promoting ability of BA compared with kinetin has also been reported for the Labiates $S$. fruticosa (Arikat et al., 2004), R. officinalis (Misra and Chaturvedi, 1984), Thymus piperella (Sáez et al., 1994), Thymus satureioides (Aicha et al., 2013), and Ocimum kilimandscharicum (Saha et al., 2010), and in S. athoa, BA induced higher shoot production compared with 2iP (Papafotiou and Kalantzis, 2009b). Moreover, BA promoted shoot multiplication in several Lavandula sp. (Gonçalves and Romano, 2013; Zuzarte et al., 2010), while 6-benzyl-aminopurine (BAP) was used in micropropagation of Mentha piperita (Santoro et al., 2013). In T. fruticans, BAP and kinetin induced similar shoot proliferation (Frabetti et al., 2009); while in T. polium, kinetin gave higher shoot production than BA (Al-Qudah et al., 2011). Kinetin was also suitable for micropropagation of $T$. stocksianum (Bouhouche and Ksiksi, 2007) and 
zeatin for Sideritis scardica (Shtereva et al., 2015), but they were not tested vs. other cytokinins. In other shrubby species of the Greek machia, such as D. fruticosus (Papafotiou and Stragas, 2009) and L. zahnii (Papafotiou and Kalantzis, 2009a), BA was the most appropriate cytokinin for shoot multiplication.

For shoot multiplication in $T$. polium (Al-Qudah et al., 2011), T. stocksianum (Bouhouche and Ksiksi, 2007), and T. fruticans (Frabetti et al., 2009) BA or kinetin was combined with an auxin [1-naphthaleneacetic acid (NAA) indole-3-acetic acid (IAA)] at low concentrations $\left(0.01-1.0 \mathrm{mg} \cdot \mathrm{L}^{-1}\right)$ and produced 2.0 to 15.0 shoots per explant; however, this effect was not tested vs. an auxin-free medium. In T. satureioides (Aicha et al., 2013) and S. athoa (Papafotiou and Kalantzis, 2009b), BA or kinetin alone induced higher shoot proliferation than when it was combined with a low concentration of auxin. In the present work, auxin along with cytokinin was not used because shoot multiplication was very satisfactory (Table 6; Fig. 1D-G) in the media tried.

Root induction and acclimatization. Microshoots excised from first to fifth subculture of the first culture established from in vitro-grown seedlings (first establishment experiment), differed in their rooting response depending on the subculture from which they originated. This was observed in both rooting techniques tested. Thus, microshoots excised from the first to the third subculture rooted at low (in most cases) and unstable percentages, unlike microshoots excised from the fourth and the fifth subculture that rooted at high percentages (Table 7). Improvement of rooting capacity as subcultures were progressing has also been reported for difficult-to-root apple cultivars (Noiton et al., 1992; Sriskandarajah et al., 1982) and rootstock M.9 (Webster and Jones, 1989), pear (Al-Maarri et al., 1994), Castanea mollissima (Hou et al., 2010), and Artocarpus heterophylllus (Amin and Jaiswal, 1993). Hou et al. (2010) found gradual increase in endogenous levels of IAA and slight decrease in endogenous levels of abscisic acid (ABA), cytokinins, and $\mathrm{GA}_{3}$ after successive subcultures.

Microshoots from fourth and fifth subculture (data shown together) rooted at higher percentages on media containing IBA, regardless of its concentration, compared with an IBA-free medium, whether microshoots remained for 1 or 5 weeks on the root induction medium, while percentage and quantity of produced callus at the base of microshoots were increased while increasing IBA concentration in the medium (Table 8; Fig. $1 \mathrm{H}$ ). Related species rooted at $\approx 100 \%$, after continuous culture on $1 / 2$ MS medium with $0.5 \mathrm{mg} \cdot \mathrm{L}^{-1} \mathrm{NAA}$ for $T$. polium (AlQudah et al., 2011), $1.0 \mathrm{mg} \cdot \mathrm{L}^{-1}$ IBA for $T$. stocksianum (Bouhouche and Ksiksi, 2007), and $0.5 \mathrm{mg} \cdot \mathrm{L}^{-1}$ IBA for $T$. fruticans (Frabetti et al., 2009). Regarding other Labiates, $S$. athoa was difficult to root and best rooting (46\% to $53 \%)$ was achieved either with $2 \mathrm{mg} \cdot \mathrm{L}^{-1}$ IBA or with $2 \mathrm{mg} \cdot \mathrm{L}^{-1} \mathrm{IBA}+1 \mathrm{mg} \cdot \mathrm{L}^{-1}$ NAA, (Papafotiou and Kalantzis, 2009b), while S. scardica rooted at $98 \%$ with 2.0 $\mathrm{mg} \cdot \mathrm{L}^{-1} \mathrm{IBA}+0.2 \mathrm{mg} \cdot \mathrm{L}^{-1} \mathrm{NAA}+0.5 \mathrm{mg} \cdot \mathrm{L}^{-1}$ gibberellic acid (Shtereva et al., 2015); $T$. satureioides (Aicha et al., 2013) and Lavandula pedunculata (Zuzarte et al., 2010) though rooted spontaneously on an HF medium, at $92 \%$ and $73 \%$, respectively. Although Lavanders' microshoots are generally easy to root on medium without auxin, the addition of NAA was necessary to achieve a high frequency of root induction in some species (Gonçalves and Romano, 2013).

Duration of culture on root induction medium not only affected rooting percentage but also number of produced roots. This was

Table 6. Effect of cytokinin type and concentration $\left(\mathrm{mg} \cdot \mathrm{L}^{-1}\right)$ on shoot multiplication from nodal explants excised from cultures established from Teucrium capitatum seedlings grown in vitro.

\begin{tabular}{|c|c|c|c|c|c|}
\hline \multicolumn{2}{|c|}{ Cytokinin } & \multirow[b]{2}{*}{ Shooting $(\%)$} & \multirow[b]{2}{*}{ Mean shoot number } & \multirow[b]{2}{*}{ Mean shoot length $(\mathrm{cm})$} & \multirow[b]{2}{*}{ Multiplication index } \\
\hline Type & $\overline{\text { Concn }}$ & & & & \\
\hline Control & 0.0 & $96.7 \pm 3.3 \mathrm{ab}^{\mathrm{z}}$ & $1.3 \pm 0.1 \mathrm{~h}$ & $3.2 \pm 0.28 \mathrm{a}$ & 6.8 \\
\hline \multirow[t]{4}{*}{ BA } & 0.5 & $100.0 \pm 0.0 \mathrm{a}$ & $13.5 \pm 1.1 \mathrm{abc}$ & $1.6 \pm 0.07 \mathrm{de}$ & 35.6 \\
\hline & 1.0 & $100.0 \pm 0.0 \mathrm{a}$ & $15.0 \pm 1.2 \mathrm{a}$ & $1.2 \pm 0.04 \mathrm{fg}$ & 29.8 \\
\hline & 2.0 & $100.0 \pm 0.0 \mathrm{a}$ & $14.1 \pm 1.0 \mathrm{ab}$ & $1.5 \pm 0.07 \mathrm{de}$ & 34.5 \\
\hline & 4.0 & $100.0 \pm 0.0 \mathrm{a}$ & $13.9 \pm 1.3 \mathrm{ab}$ & $1.0 \pm 0.03 \mathrm{~g}$ & 22.0 \\
\hline \multirow[t]{4}{*}{ Zeatin } & 0.5 & $100.0 \pm 0.0 \mathrm{a}$ & $3.9 \pm 0.5 \mathrm{gh}$ & $1.9 \pm 0.16 \mathrm{c}$ & 12.4 \\
\hline & 1.0 & $100.0 \pm 0.0 \mathrm{a}$ & $5.6 \pm 0.6 \mathrm{fg}$ & $1.6 \pm 0.13 \mathrm{de}$ & 14.7 \\
\hline & 2.0 & $100.0 \pm 0.0 \mathrm{a}$ & $7.6 \pm 0.9 \mathrm{ef}$ & $1.3 \pm 0.08 \mathrm{ef}$ & 16.8 \\
\hline & 4.0 & $93.3 \pm 4.2 \mathrm{~b}$ & $10.6 \pm 1.0 \mathrm{~cd}$ & $0.9 \pm 0.03 \mathrm{~g}$ & 14.6 \\
\hline \multirow[t]{4}{*}{ Kinetin } & 0.5 & $100.0 \pm 0.0 \mathrm{a}$ & $6.7 \pm 0.9$ ef & $2.3 \pm 0.14 \mathrm{~b}$ & 25.5 \\
\hline & 1.0 & $100.0 \pm 0.0 \mathrm{a}$ & $11.4 \pm 1.5 \mathrm{bc}$ & $1.7 \pm 0.10 \mathrm{~cd}$ & 32.1 \\
\hline & 2.0 & $100.0 \pm 0.0 \mathrm{a}$ & $10.9 \pm 1.3 \mathrm{~cd}$ & $1.5 \pm 0.06 \mathrm{de}$ & 27.6 \\
\hline & 4.0 & $100.0 \pm 0.0 \mathrm{a}$ & $14.0 \pm 1.2 \mathrm{ab}$ & $0.9 \pm 0.05 \mathrm{~g}$ & 21.9 \\
\hline \multirow[t]{4}{*}{$2 \mathrm{iP}$} & 0.5 & $100.0 \pm 0.0 \mathrm{a}$ & $6.7 \pm 0.9 \mathrm{ef}$ & $1.5 \pm 0.08 \mathrm{de}$ & 16.8 \\
\hline & 1.0 & $93.3 \pm 4.2 b$ & $11.9 \pm 1.1 \mathrm{bc}$ & $1.9 \pm 0.09 \mathrm{c}$ & 34.1 \\
\hline & 2.0 & $86.7 \pm 4.2 \mathrm{c}$ & $8.8 \pm 1.2 \mathrm{de}$ & $1.2 \pm 0.08 \mathrm{fg}$ & 16.1 \\
\hline & 4.0 & $100.0 \pm 0.0 \mathrm{a}$ & $11.8 \pm 1.2 \mathrm{bc}$ & $1.3 \pm 0.04 \mathrm{ef}$ & 25.8 \\
\hline
\end{tabular}

$\mathrm{BA}=6$-benzyladenine, $2 \mathrm{iP}=6-\gamma-\gamma$-(dimethylallylamino)-purine.

${ }^{z}$ Mean $( \pm \mathrm{SE})$ separation in columns per each subculture by Student's $t$ test at $P \leq 0.05$.

Multiplication index $=$ shooting $(\%) \times$ mean shoot number per explant $\times$ mean shoot length/0.6.

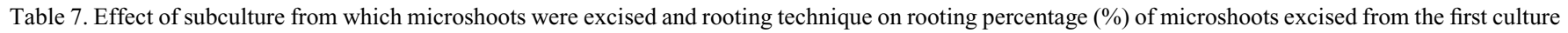
established from Teucrium capitatum seedlings grown in vitro.

\begin{tabular}{|c|c|c|c|c|c|c|}
\hline \multirow[b]{2}{*}{ IBA culture duration } & \multirow[b]{2}{*}{$\operatorname{IBA}\left(\mathrm{mg} \cdot \mathrm{L}^{-1}\right)$} & \multicolumn{5}{|c|}{ Subculture from which microshoots were excised } \\
\hline & & First & Second & Third & Fourth & Fifth \\
\hline \multirow[t]{5}{*}{5 weeks } & 0.0 & $10.0 \pm 5.8 \mathrm{a}^{\mathrm{z}}$ & $12.5 \pm 4.8 \mathrm{a}$ & $7.5 \pm 4.8 \mathrm{a}$ & $40.0 \pm 14.1 \mathrm{a}$ & $30.0 \pm 5.8 \mathrm{a}$ \\
\hline & 0.5 & $35.0 \pm 9.6 \mathrm{~b}$ & $25.0 \pm 5.0 \mathrm{~b}$ & $20.0 \pm 0.0 \mathrm{~b}$ & $64.0 \pm 14.7 \mathrm{a}$ & $90.0 \pm 5.8 \mathrm{a}$ \\
\hline & 1.0 & $35.0 \pm 5.0 \mathrm{~b}$ & $45.0 \pm 5.0 \mathrm{~b}$ & $0.0 \pm 0.0 \mathrm{c}$ & $48.0 \pm 8.0 \mathrm{~b}$ & $95.0 \pm 5.0 \mathrm{a}$ \\
\hline & 2.0 & $40.0 \pm 8.2 \mathrm{~b}$ & $32.5 \pm 4.8 b$ & $10.0 \pm 4.1 \mathrm{c}$ & $68.0 \pm 4.9 \mathrm{a}$ & $80.0 \pm 11.5 \mathrm{a}$ \\
\hline & 4.0 & - & - & $45.0 \pm 15.0 \mathrm{~b}$ & $84.0 \pm 7.5 \mathrm{a}$ & $75.0 \pm 15.0 \mathrm{ab}$ \\
\hline \multirow{5}{*}{$\begin{array}{l}1 \text { week (followed by transfer } \\
\text { to HF } 1 / 2 \text { MS for } 4 \text { weeks) }\end{array}$} & 0.0 & - & - & - & $44.0 \pm 11.7 \mathrm{a}$ & $50.0 \pm 5.8 \mathrm{a}$ \\
\hline & 0.5 & - & $40.0 \pm 8.2 \mathrm{c}$ & $25.0 \pm 5.0 \mathrm{~d}$ & $100.0 \pm 0.0 \mathrm{a}$ & $80.0 \pm 0.0 \mathrm{~b}$ \\
\hline & 1.0 & - & $45.0 \pm 5.0 \mathrm{~b}$ & $60.0 \pm 14.1 \mathrm{~b}$ & $88.0 \pm 8.0 \mathrm{a}$ & $100.0 \pm 0.0 \mathrm{a}$ \\
\hline & 2.0 & - & $100.0 \pm 0.0 \mathrm{a}$ & $40.0 \pm 21.6 b$ & $96.0 \pm 4.0 \mathrm{a}$ & $100.0 \pm 0.0 \mathrm{a}$ \\
\hline & 4.0 & - & - & $50.0 \pm 12.9 \mathrm{~b}$ & $96.0 \pm 4.0 \mathrm{a}$ & $100.0 \pm 0.0 \mathrm{a}$ \\
\hline
\end{tabular}

$\mathrm{HF}=$ hormone-free medium; 1/2 MS = half-strength Murashige and Skoog (1962) growth medium; IBA = indole-3-butyric acid.

${ }^{z}$ Mean $( \pm \mathrm{SE})$ separation in lines by Student's $t$ test at $P \leq 0.05$. 
Table 8. Effect of indole-3-butyric acid (IBA) concentration and duration of culture on the IBA medium on rooting of Teucrium capitatum microshoots excised from culture established from seedlings grown in vitro, during the fourth and fifth subculture.

\begin{tabular}{|c|c|c|c|c|c|}
\hline \multirow{3}{*}{$\frac{\text { IBA culture duration }}{5 \text { weeks }}$} & IBA $\left(\mathrm{mg} \cdot \mathrm{L}^{-1}\right)$ & Callus (\%) & Rooting (\%) & Mean root number & Mean root length $(\mathrm{cm})$ \\
\hline & 1.0 & $75.0 \pm 9.6 \mathrm{ab}$ & $68.9 \pm 9.5 \mathrm{c}$ & $5.2 \pm 0.5 \mathrm{~d}$ & $1.8 \pm 0.3 \mathrm{cde}$ \\
\hline & 2.0 & $70.0 \pm 12.9 \mathrm{ab}$ & $73.3 \pm 5.8 \mathrm{c}$ & $5.7 \pm 0.6 \mathrm{~cd}$ & $1.3 \pm 0.2 \mathrm{de}$ \\
\hline \multirow{3}{*}{$\begin{array}{l}1 \text { week (followed by transfer } \\
\text { to } \mathrm{HF} 1 / 2 \mathrm{MS} \text { for } 4 \text { weeks) }\end{array}$} & 0.0 & $0.0 \pm 0.0 \mathrm{c}$ & $46.7 \pm 5.8 \mathrm{~d}$ & $3.1 \pm 0.4 \mathrm{e}$ & $3.8 \pm 0.6 \mathrm{a}$ \\
\hline & 0.5 & $25.0 \pm 9.6 \mathrm{c}$ & $91.1 \pm 3.5 \mathrm{ab}$ & $5.1 \pm 0.4 \mathrm{~d}$ & $2.8 \pm 0.4 \mathrm{~b}$ \\
\hline & 1.0 & $65.0 \pm 9.6 \mathrm{~b}$ & $93.3 \pm 4.7 \mathrm{ab}$ & $7.2 \pm 0.4 \mathrm{ab}$ & $2.4 \pm 0.2 \mathrm{bc}$ \\
\hline $\mathrm{F}_{\text {IBA culture duration }}$ & & NS & $* *$ & $* *$ & $* *$ \\
\hline $\mathrm{F}_{\mathrm{IBA} \text { concentration }}$ & & $* *$ & $* *$ & ** & ** \\
\hline$\underline{F_{\text {interaction }}}$ & & NS & NS & NS & NS \\
\hline
\end{tabular}

$\mathrm{HF}=$ hormone-free medium; $1 / 2 \mathrm{MS}$ = half-strength Murashige and Skoog (1962) growth medium; IBA = indole-3-butyric acid.

${ }^{z}$ Mean $( \pm \mathrm{SE})$ separation in columns by Student's $t$ test at $P \leq 0.05$.

Ns, **Nonsignificant or significant at $P \leq 0.01$, respectively.

more obvious at higher IBA concentrations. So, microshoots cultured on $1 / 2$ MS medium with $1.0-4.0 \mathrm{mg} \cdot \mathrm{L}^{-1} \mathrm{IBA}$ for 1 week rooted at significantly higher percentage and formed significantly more roots per microshoot than those cultured on the same media continuously for 5 weeks (Table 8; Fig. 1H). About 1 -week culture on root induction medium containing auxin, followed by transfer to an auxin-free medium for root growth has also been used in rooting apple microshoots (Lane, 1992; Liu et al., 1991) and those of the endangered difficult-to-root $\times$ Malosorbus florentina (Martini and Papafotiou, 2009, 2013), improving rooting and preventing callus formation. Although auxins stimulate formation of root meristemoids during the induction phase, they can become inhibitory and block outgrowth of root primordia, once meristemoids have been formed. An auxin concentration that is optimal for one phase may be supraoptimal for the next, because of the differences in auxin requirements among the three phases of adventitious rooting (dedifferentiation, induction, and outgrowth) (De Klerk et al., 1999). Moreover, when IBA is supplied to the microcutting for a protracted period of time, it may remain present for a long time because of its stability and may then inhibit the outgrowth of root primordia (De Klerk et al., 1990).

As regard IBA concentration, more roots per microshoot were formed at 1.0-4.0 $\mathrm{mg} \cdot \mathrm{L}^{-1}$ compared with lower concentrations $0.0-0.5 \mathrm{mg} \cdot \mathrm{L}^{-1}$ (Table 8; Fig. 1H). Length of produced roots was significantly affected by concentration of IBA. As concentration of IBA was increasing, length of produced roots was decreasing. The greatest root length was recorded by microshoots cultured on IBAfree medium for 1 week and transferred to fresh medium for the following 4 weeks of culture (Table 8; Fig. 1H). Duration of culture on the IBA medium did not affect root elongation significantly (Table 8; Fig. 1H).

Plantlets were successfully acclimatized ex vitro with $98 \%$ survival at $40 \mathrm{~d}$ after their transfer to the greenhouse, while all acclimatized plants survived after transplantation into pots (Fig. 1I) and grew vigorously
(Fig. 1J) for more than 1 year. Similarly, high acclimatization percentages were reported for T. fruticans (Frabetti et al., 2009), T. satureioides (Aicha et al., 2013), and Lavandula vera (Gonçalves and Romano, 2013), while plantlets of $T$. polium (Al-Qudah et al., 2011), T. stocksianum (Bouhouche and Ksiksi, 2007), and other aromatics, such as $S$. friticosa (Arikat et al., 2004), T. piperella (Sáez et al., 1994), O. kilimandscharicum (Saha et al., 2010), $S$. scardica (Shtereva et al., 2015), and various lavenders (Gonçalves and Romano, 2013; Sánchez-Gras and Calvo, 1996) were acclimatized at little lower percentages ( $70 \%$ to $85 \%)$.

In conclusion, although germination capacity of $T$. capitatum seeds was increased by acid scarification it still remained low. Thus, micropropagation was found more efficient method for commercial propagation of the species. Explant origin was shown as determinant for its success, since explants excised from in vitro-grown seedlings were established at much higher rates compared with those collected from plants grown from cuttings in a greenhouse. Higher shoot multiplication rates and uniform response could be succeeded if initial explants were excised from branched seedlings, BA at $0.5-2.0 \mathrm{mg} \cdot \mathrm{L}^{-1}$ induced high shoot multiplication during both establishment and multiplication stage, and rooting and acclimatization were highly successful.

\section{Literature Cited}

Aicha, N., T.C. Rachida, and E.L.M. Abdelmalek. 2013. Micropropagation of Thymus satureioides Coss. an endangered medicinal plant of Morocco. J. Agr. Technol. 9:487-501.

Al-Maarri, K., Y. Arnaud, and E. Miginiac. 1994. Micropropagation of Pyrus communis cultivar 'Passe Crassane' seedlings and cultivar 'Williams': Factors affecting root formation in vitro and ex vitro. Sci. Hort. 58:207-214.

Al-Qudah, T.S., R.A. Shibli, and F.Q. Alali. 2011. In vitro propagation and secondary metabolites production in wild germander (Teucrium polium L.). In Vitro Cell. Dev. Biol. Plant 47:496-505.

Amin, M.N. and V.S. Jaiswal. 1993. In vitro response of apical bud explants from mature trees of jackfruit (Artocarpus heterophyllus). Plant cell Tiss. Org. Cult. 33:59-65.

Antunes, T., I. Sevinate-Pinto, J.G. Barroso, C. Cavaleiro, and L.R. Salgueiro. 2004. Micromorphology of trichomes and composition of essential oil of Teucrium capitatum. Flavour Fragrance J. 19:336-340.

Arikat, N.A., F.M. Jawad, N.S. Karam, and R.A. Shibli. 2004. Micropropagation and accumulation of essential oils in wild sage (Salvia fruticosa Mill.). Sci. Hort. 100:193202.

Bahramikia, S. and R. Yazdanparast. 2012. Phytochemistry and medicinal properties of Teucrium polium L. (Lamiaceae). Phytother. Res. 26:1581-1593.

Ballester, A., M.C. Sánchez, M.C. San-José, F.J. Vieitez, and A.M. Vietez. 1990. Development of rejuvenation methods for in vitro establishment, multiplication and rooting of mature trees, p. 43-49. In: R. Rodríguez, R. Sánchez Tamés, and D.J. Durzan (eds.). Plant aging: Basic and applied approaches. Plenum Press, New York, NY.

Barroso, F.G., C.L. Alados, and J. Boza. 1995. Food selection by goats in Mediterranean arid scrublands. J. Arid Environ. 31:205-217.

Bertsouklis, K.F. and M. Papafotiou. 2010. Studies on propagation of Globularia alypum L. Acta Hort. 885:73-77.

Blamey, M. and C. Grey-Wilson. 1993. Mediterranean wild flowers. HarperCollins Publishers, London, UK.

Bonga, J.M. 1981. Vegetative propagation of mature trees by tissue culture, p. 191-196. In: A.N. Rao (ed.). Proc. Costed Sym. On Tissue Cult. Eco. Imp. Plants, Singapore.

Bouhouche, N. and T. Ksiksi. 2007. An efficient in vitro plant regeneration system for the medicinal plant Teucrium stocksianum Boiss. Plant Biotechnol. Rpt. 1:179-184.

Chaturvedi, H.C., J. Madhu, and N.R. Kidwai. 2007. Cloning of medicinal plants through tissue culture-A review. Indian J. Expt. Biol. 45:937-948.

Cozzani, S., A. Muselli, J.M. Desjobert, A.F. Bernardini, F. Tomi, and J. Casanova. 2005. Chemical composition of essential oil of Teucrium polium subsp. capitatum (L.) from Corsica. Flavour Fragrance J. 20:436-441.

Debnath, M., C.P. Malik, and P.S. Bisen. 2006. Micropropagation: A tool for the production of high quality plant-based medicines. Curr. Pharm. Biotechnol. 7:33-49.

De Klerk, G.J., W.V. Der Krieken, and J.C. De Jong. 1999. Review. The formation of 
adventitious roots: New concepts, new possibilities. In Vitro Cell. Dev. Biol. Plant 35:189199.

De Klerk, G.J., J. Ter Brugge, R. Smulders, and M. Benschop. 1990. Basic peroxidases and rooting in microcuttings of Malus. Acta Hort. 280:29-36.

Djabou, N., A. Muselli, H. Allali, M. El Amine Dib, B. Tabti, L. Varesi, and J. Costa. 2012. Chemical diversity of two Mediterranean subspecies of Teucrium polium L. Phytochemistry 83:51-62.

Fay, M.F. 1994. In what situations is in vitro culture appropriate to plant conservation? Biodivers. Conserv. 3:176-183.

Frabetti, M., P. Gutiérrez-Pesce, E. Mendoza-de Gyves, and E. Rugini. 2009. Micropropagation of Teucrium fruticans L., an ornamental and medicinal plant. In Vitro Cell. Dev. Biol. Plant 45:129-134.

Gonçalves, S. and A. Romano. 2013. In vitro culture of lavanders (Lavandula spp.) and the production of secondary metabolites. Biotechnol. Adv. 31:166-174.

Hou, J., S. Guo, and G. Wang. 2010. Effects of in vitro subculture on the physiological characteristics of adventitious root formation of Castanea mollissima cv 'yanshanhong'. J. For. Res. 21:155-160.

Kelly, K.M., J. Van Staden, and W.E. Bell. 1992. Seed coat structure and dormancy. Plant Growth Regulat. 11:201-209.

Kerbouche, L., M. Hazzit, M.-A. Ferhat, A. Baaliouamer, and M.G. Miguel. 2015. Biological activities of essential oils and ethanol extracts of Teucrium polium subsp. capitatum (L.) Briq. and Origanum floribundum Munby. Journal of Essential Oil Bearing Plants 18:1197-1208.

Lane, W.D. 1992. Micropropagation of apple (Malus domestica Borkh.), p. 229-243. In: Y.P.S. Bajaj (ed.). Biotechnology in agriculture and forestry. Vol. 18: High-tech and Micropropagation II, Springer-Verlag, Berlin.

Liu, P.Z., S.T. He, L.X. Han, and J.S. Wang. 1991. Study on rooting techniques for apple in vitro. J. Fruit Sci. 8:139-144.

Luna, B. and J.M. Moreno. 2009. Light and nitrate effects on seed germination of Mediterranean plant species of several functional groups. Plant Ecol. 203:123-135.

Luna, B., J.M. Moreno, A. Cruz, and F. FernándezGonzález. 2007. Heat-shock and seed germination of a group of Mediterranean plant species growing in a burned area: An approach based on plant functional types. Environ. Expt. Bot. 60:324-333.

Marks, T.R. and P.E. Myers. 1992. Evidence for bud origin influencing performance during micropropagation. Acta Hort. 314:205-212.

Marks, T.R. and P.E. Myers. 1994. Physiological variability arising from in vitro culture is induced by shoot selection and manipulation strategies. J. Hort. Sci. 69:1-9.

Martini, A.N. and M. Papafotiou. 2009. In vitro rooting of xMalosorbus florentina Zucc. microshoots. Acta Hort. 813:491-496.

Martini, A.N. and M. Papafotiou. 2013. Effects of plant growth regulators and environmental factors on in vitro propagation of xMalosorbus florentina. Propag. Ornam. Plants 13:112-122.

Menichini, F., F. Conforti, D. Rigano, C. Formisano, F. Piozzi, and F. Senatore. 2009. Phytochemical composition, anti-inflammatory and antitumour activities of four Teucrium essential oils from Greece. Food Chem. 115:679-686.

Misra, P. and H.C. Chaturvedi. 1984. Micropropagation of Rosmarinus officinalis L. Plant Cell Tiss. Org. Cult. 3:163-168.

Mitić, V., O. Jovanović, V. Stankov-Jovanović, B. Zlatkovic, and G. Stojanovic. 2012. Analysis of the essential oil of Teucrium polium ssp. capitatum from the Balkan Peninsula. Natl. Prod. Commun. 7:83-86.

Morbidoni, M., E. Estrelles, P. Soriano, I. Martínez-Solís, and E. Biondi. 2008. Effects of environmental factors on seed germination of Anthyllis barba-jovis L. Plant Biosyst. 142:275-286.

Moreira, B., J. Tormo, E. Estrelles, and J.G. Pausas. 2010. Disentangling the role of heat and smoke as germination cues in Mediterranean Basin flora. Ann. Bot. (Lond.) 105:627-635.

Murashige, T. and F. Skoog. 1962. A revised medium for rapid growth and bioassays with tobacco tissue cultures. Physiol. Plant. 15:473-497.

Nadjafi, F., M. Bannayan, L. Tabrizi, and M. Rastgoo. 2006. Seed germination and dormancy breaking techniques for Ferula gummosa and Teucrium polium. J. Arid Environ. 64:542-547.

Nobre, J. 1996. In vitro cloning and micropropagation of Lavandula stoechas from field-grown plants. Plant Cell Tiss. Org. Cult. 46:151-155.

Noiton, D., J.H. Vine, and M.G. Mullins. 1992 Effects of serial subculture in vitro on the endogenous levels of indole-3-acetic acid and abscisic acid and roootability in microcuttings of 'Jonathan' apple. Plant Growth Regulat. 11:377-383.

Papafotiou, M., A. Akoumianaki, A.N. Martini, and G. Vlachou. 2013. Propagation of Teucrium capitatum $\mathrm{L}$. by seed and cuttings. $26^{\text {th }}$ Panhellenic Scientific Conference, 15-18 Oct. 2013, Kalamata, Greece. Proc. Hellenic Soc. Hort. Sci. 16:(In press).

Papafotiou, M. and A. Kalantzis. 2009a. Studies on in vitro propagation of Lithodora zahnii. Acta Hort. 813:465-470.

Papafotiou, M. and A. Kalantzis. 2009b. Seed germination and in vitro propagation of Sideritis athoa. Acta Hort. 813:471-476.

Papafotiou, M. and J. Stragas. 2009. Seed germination and in vitro propagation of Dianthus fruticosus L. Acta Hort. 813:481-484.

Pierik, R.L.M. 1990. Rejuvenation and micropropagation, p. 91-101. In: H.J.J. Nijkamp, L.H.W. Van Der Plas, and J. Van Aatrijk (eds.). Progress in plant cellular and molecular biology. Vol. 9: Current plant science and biotechnology in agriculture. Kluwer Academic Publishers, Dordrecht, The Netherlands.

Rabba'a, M.M., R.A. Shibli, and M.A. Shatnawi. 2012. Cryopreservation of Teucrium polium L. shoot-tips by vitrification and encapsulationdehydration. Plant Cell Tissue Organ Cult. 110:371-382.

Rolston, M.P. 1978. Water impermeable seed dormancy. Botanic. Rev. 44:365-396.

Romão, R.L. and A. Escudero. 2005. Gypsum physical soil crusts and existence of gypsophytes in semi-arid central Spain. Plant Ecol. 181:127-137.

Sáez, F., P. Sánchez, and A. Piqueras. 1994. Micropropagation of Thymus piperella. Plant Cell Tiss. Org. Cult. 39:269-272.
Saha, S., T. Dey, and P. Ghosh. 2010. Micropropagation of Ocimum kilimandscharicum Guerke (Labiatae). Acta Biol. Cracov. Ser. Bot. 52:50-58.

Sahoo, Y. and P.K. Chand. 1998. Micropropagation of Vitex negundo L., a woody aromatiic medicinal shrub, through high-frequency axillary shoot proliferation. Plant Cell Rpt. 18:301-307.

Sánchez-Gras, M.C. and M.C. Calvo. 1996. Micropropagation of Lavandula latifolia through nodal bud culture of mature plants. Plant Cell Tiss. Org. Cult. 45:259-261.

Santoro, M.V., F. Nievas, J. Zygadlo, W. Giordano, and E. Banchio. 2013. Effects of growth regulators on biomass and the production of secondary metabolites in peppermint (Mentha piperita) micropropagated in vitro. Amer. J. Plant Sci. 4:49-55.

Sarwar, M., R.M. Skirvin, M. Kushad, and M.A. Morton. 1998. Selecting dwarf apple (Malus x domestica Borkh.) trees in vitro: Multiple cytokinin tolerence expressed among three strains of 'McIntosh' that differ in their growth habit under field conditions. Plant Cell Tiss. Org. Cult. 54:71-76.

Shtereva, L.A., R.D. Vassilevska-Ivanova, and B.V. Kraptchev. 2015. In vitro cultures for micropropagation, mass multiplication and preservation of an endangered medicinal plant Sideritis scardica Griseb. Botanica Serbica 39:111-120.

Sriskandarajah, S., M.G. Mullins, and Y. Nair. 1982. Induction of adventitious rooting in difficult-to-propagate cultivars of apple. Plant Sci. Lett. 24:1-9.

Stefkov, G., S. Kulevanova, B. Miova, S. DinevskaKjovkarovska, P. Mølgaard, A.K. Jäger, and K. Josefsen. 2011. Effects of Teucrium polium spp. capitatum flavonoids on the lipid and carbohydrate metabolism in rats. Pharm. Biol. 49:885-892.

Thanos, C.A. and M.A. Doussi. 1995. Ecophysiology of seed germination in endemic Labiates of Crete. Israel J. Plant Sci. 43:227-237.

Thanos, C.A., C.C. Kadis, and F. Skarou. 1995. Ecophysiology of germination in the aromatic plants thyme, savory and oregano (Labiatae). Seed Sci. Res. 5:161-170.

Theophrastus, Enquiry into Plants, Volume II: Books 6-9. On Odours. Weather Signs. Translated by Arthur F. Hort. Loeb Classical Library 79. Harvard University Press, Cambridge, MA.

Tripathi, L. and J.N. Tripathi. 2003. Role of biotechnology in medicinal plants. Trop. J. Pharm. Res. 2:243-253.

Webster, C.A. and O.P. Jones. 1989. Micropropagation of the apple rootstock M.9: Effect of sustained subculture on apparent rejuvenation in vitro. J. Hort. Sci. 64:421-428.

Zimmerman, R.H. 1986. Regeneration in woody ornamentals and fruit trees, p. 243-258. In: I.K. Vasil (ed.). Cell culture and somatic cell genetics. Vol. 3: Plant Regeneration and Genetic Variability, Academic Press, New York.

Zuzarte, M.R., A.M. Dinis, C. Cavaleiro, L.R. Salgueiro, and J.M. Canhoto. 2010. Trichomes, essential oils and in vitro propagation of Lavandula pedunculata (Lamiaceae). Ind. Crops Prod. 32:580-587. 